\title{
Systemic Therapy of Cholangiocarcinoma
}

\author{
Ruben R. Plentz Nisar P. Malek \\ Department of Internal Medicine I, Medical University Hospital, Tübingen, Germany
}

Keywords

Chemotherapy $\cdot$ Cholangiocarcinoma $\cdot$ Survival

\section{Summary}

Background: Cholangiocarcinoma (CC) is the second most common primary malignant liver disease. During the last decades, various novel therapies have been introduced in the field of oncology; nevertheless, the number of treatment options for CC is still limited. Methods: In this article, current palliative chemotherapy concepts as well as new drug therapies are outlined. Results: Gemcitabine and cisplatin are the standard treatment of care for patients with inoperable CC. Second-line chemotherapy is not standardized yet and is dependent on the first-line compounds. Antibodies against VEGFR and EGFR showed mixed or negative results. New molecular systemic treatments are not established yet. Conclusion: Many clinical trials are still ongoing and new therapeutic strategies, including immunotherapies, are under active investigation.

(C) 2016 S. Karger GmbH, Freiburg

\section{Introduction}

Cholangiocarcinoma (CC) is a rare but increasing tumor disease, and many patients (80\%) present with unresectable intra- and extrahepatic metastases or advanced tumor stage at diagnosis [15]. The median survival of untreated patients with unresectable CC is approximately 3-6 months [6]. Therefore, the majority of patients are undergoing palliative systemic chemotherapy. Even though large phase III trials are missing, the role of chemotherapy is evidence-based and has a fixed place in the palliative setting.

\section{Adjuvant Chemotherapy}

The role of adjuvant chemotherapy or chemoradiation after complete resection is not clear yet (fig. 1). The local recurrence, especially of extrahepatic CC, is high, and the European (European Society for Medical Oncology (ESMO)) as well as the US (National Comprehensive Cancer Network (NCCN)) guidelines mention adjuvant therapy as an option $[7,8]$. After R0 resection without lymph node involvement, both guidelines recommend chemotherapy with gemcitabine or 5 -fluorouracil (5-FU). In contrast, patients with $\mathrm{R} 1$ resection or positive lymph nodes could be treated by chemoradiotherapy. The SWOG-S0809 study recently showed that sequential chemotherapy with gemcitabine and capecitabine for 12 weeks followed by radiochemotherapy led to promising results [9]. The further role of adjuvant chemotherapy will be evaluated in three large, currently ongoing phase III studies (BILCAP, PRODIGE-12, ACTICCA-1) in three different European countries (France, Germany, UK).

\section{Palliative Chemotherapy}

Retrospectively, systemic chemotherapy with a combination of 5-FU as well as leucovorin with and without etoposide improved survival [10]. Phase II trials with 5-FU demonstrated response rates between 10 and 34\% [11, 12]. However, the combination of 5-FU/ capecitabine and platinum (cisplatin/oxaliplatin) compounds did not improve the tumor response rates significantly [13-17]. So far, different chemotherapeutic drugs have been tested: Gemcitabine as a monotherapy showed response rates between 17.5 and $36 \%$ [18, 19]. Gemcitabine and capecitabine showed response rates of $25 \%$ [20-24], and oxaliplatin and gemcitabine showed response rates of $50 \%$ [25-27]. Since 2010, a combination therapy with gemcitabine and cisplatin is considered as the standard first-line chemotherapy for non-resectable CC [28]. In this ABC-02 phase III trial, a significantly longer median survival in the combination group compared to gemcitabine monotherapy (11.7 vs. 8.1 months) was achieved (fig. 1). However, patients with impairment of renal function can

\section{KARGER \\ Fax +497614520714

๑๑ 2016 S. Karger GmbH, Freiburg 


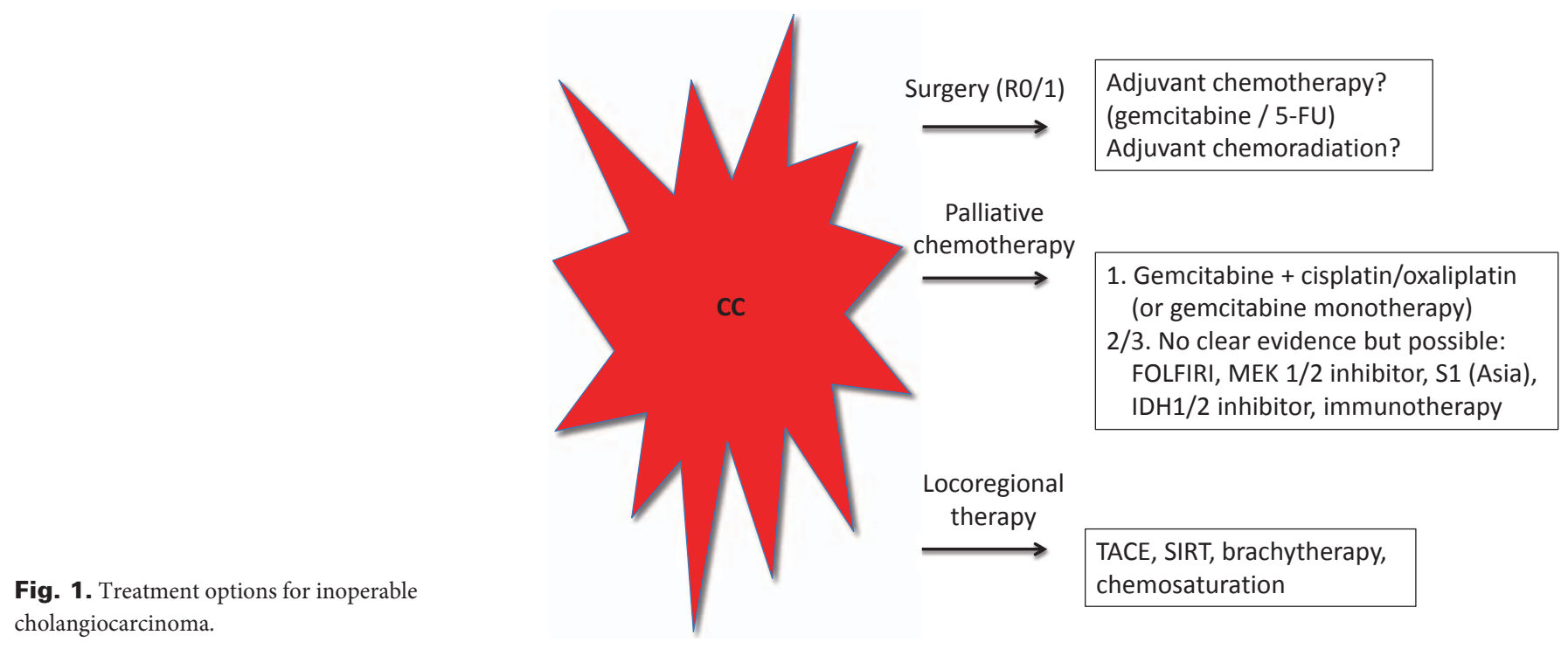

also be treated with oxaliplatin. Monotherapy with gemcitabine is mainly recommended for elderly patients or patients with impaired ECOG (Eastern Cooperative Oncology Group) performance status or significant additional diseases.

\section{Second-Line Chemotherapy}

For the use of second-line chemotherapy, there is currently no clear evidence, while large studies are missing. Thus, the median survival in both a Japanese phase II study as well as in the larger ABC-02 phase III study with gemcitabine and cisplatin was 11.7 and 11.2 months, respectively [29]. Interestingly, in the Japanese study, $75 \%$ of the patients received a subsequent therapy, while second-line treatment was only applied in $15 \%$ of all patients in the $\mathrm{ABC}-02$ trial. One of the biggest retrospective analyses examined the use of various chemotherapeutic drugs after failure of gemcitabine and showed a better survival compared to best supportive care [30]. A systematic review of second-line chemotherapies in CC analyzed data of 761 patients [31]. The median progressionfree survival (PFS) and overall survival (OS) was 3.2 and 7.2 months, respectively. The response rates and the tumor control rates were low with 7.7 and $48 \%$, respectively. However, in daily practice it is not uncommon and probably justified to offer patients with good performance status a second-line chemotherapy.

\section{New Targets and Therapies}

New clinical targeted and immunotherapeutic trials with peptide-based vaccines, dendritic cell-based vaccines, and antibodies have been initiated. In more detail, immunotherapeutic approaches are divided into passive and active immunotherapies. For passive immunotherapy, antibodies against epidermal growth factor receptor (EGFR) and vascular endothelial growth factor receptor
(VEGFR) were investigated. Currently, the most studied aspect is EGFR inhibition. EGFR expression is frequently observed in intrahepatic CC but only 5-32\% of cancers show true overexpression of the EGFR compared to normal tissues. Interestingly, KRAS mutations occur significantly less often in CC compared to other types of cancer [32-35]. In a single-arm study by Gruenberger et al. [36], the chimeric EGFR antibody cetuximab in combination with GEMOX achieved response rates of $63 \%$. However, the data of the randomized phase II BINGO study were disappointing. This trial did not show an advantage for the combination of cetuximab with GEMOX [37]. It is possible that KRAS mutations are causing resistance to EGFR-targeted therapy. However, a phase II study from Asia found no benefit of EGFR targeting in patients with CC and KRAS wildtype [38]. The German PICCA study also showed no benefit for the treatment with panitumumab [39]. Regarding patients with CC, gallbladder carcinoma, or papillary cancer, another study has tested the combination of GEMOX and the tyrosine kinase inhibitor erlotinib; adding erlotinib showed no benefit in patients with CC, though [40]. In the subgroup analysis, patients treated with erlotinib showed a prolonged PFS; however, it is not yet clear whether overexpression of EGFR is a prerequisite for the efficacy of erlotinib treatment. Erlotinib was also tested in combination with the VEGFR antibody bevacizumab. A tolerable toxicity with response rates of $12 \%$ has been demonstrated [41]. The PFS was 4.4 months and the OS 9.9 months. A combination of gemcitabine, oxaliplatin, and bevacizumab (antibody against VEGFR) showed a tumor response measured by fluorodeoxyglucose-positron emission tomography [42].

The multikinase inhibitor sorafenib approved for the treatment of hepatocelluar and kidney cancer showed no significant anti-tumor activity $[43,44]$. Moreover, the combination of sorafenib and gemcitabine showed no improvement of survival in patients with CC $[45,46]$. The same is true for the combination of sorafenib and erlotinib which did not show a benefit in patients with CC [47]. Another tyrosine kinase inhibitor, cediranib, which was tested in a 
phase II study in combination with gemcitabine and cisplatin, did not show an advantage [48]. Sunitinib, another multikinase inhibitor tested in the second-line setting, demonstrated a PFS of 1.7 months, while the response rate was $8.9 \%$ [49]. Furthermore, the multi-targeted tyrosine kinase inhibitor vandetanib (inhibition of EGFR and VEGFR) in combination with gemcitabine showed no survival benefit [50]. Recently, the MEK $1 / 2$ inhibitor selumetinib was tested in patients with CC and showed response rates of $12 \%$, a PFS of 3.7 months, and an OS of 9.8 months [51]. In addition, the oral prodrug of 5-FU (S1), which is used mainly in Asia, was tested in combination with gemcitabine and cisplatin $[52,53]$. The combination therapy with gemcitabine resulted in a response rate of $20 \%$, but the combination did not differ from monotherapies. Yet another therapeutic approach, i.e. the combination of a c-MET inhibitor (tivantinib) and gemcitabine, was evaluated and achieved a partial response in 1 patient [54]. In a second study, unselected patients were treated with cabozantinib (inhibitor of c-MET) but did not result in a meaningful response [55]. The incidence of mutations of isocitrate dehydrogenase 1 and 2 (IDH1/2), which is essential for the cellular response to oxidative stress, is approximately $20 \%$ for intrahepatic CC $[56,57]$. IDH inhibitors are also currently being evaluated in clinical trials (fig. 1).
As an active immunotherapeutic approach, Aruga et al. [58] combined different peptides in a palliative setting. Here, the median PFS was 156 days and the OS 380 days. It was also shown that programmed cell death ligand 1 (PD-L1) and human leukocyte antigen (HLA) class I is expressed in human intrahepatic CC [59]. The authors confirmed that positive HLA class I expression in combination with negative/low PD-L1 expression was associated with better clinical disease and that their findings support the usage of immunotherapeutic checkpoint inhibitors. Besides, Gani et al. [60] showed that PD-L1 was expressed in the majority of intrahepatic CC and that PD-L1 expression was associated with decreased survival. However, the role of immune checkpoint inhibitors against CC is not fully investigated yet. Different studies with non-colorectal cancers, including CC, treated with pembrolizumab are not published. Also, the role of defects in mismatch repair genes for CC carcinogenesis is not completely understood. Further immune checkpoint blockade therapies are warranted, and immunotherapeutic approaches for $\mathrm{CC}$ are not the standard of care yet.

\section{Disclosure Statement}

No conflicts of interest.

\section{References}

1 Wang Y, Li J, Xia Y, et al: Prognostic nomogram for intrahepatic cholangiocarcinoma after partial hepatectomy. J Clin Oncol 2013;31:1188-1195.

2 West J, Wood H, Logan RF, Quinn M, Aithal GP: Trends in the incidence of primary liver and biliary tract cancers in England and Wales 1971-2001. Br J Cancer 2006;94:1751-1758.

3 Shaib YH, Davila JA, McGlynn K, El Serag HB: Rising in cidence of intrahepatic cholangiocarcinoma in the United States: a true increase? J Hepatol 2004;40:472-477.

4 Alvaro D, Crocetti E, Ferretti S, Bragazzi MC, Capocaccia R: Descriptive epidemiology of cholangiocarcinoma in Italy. Dig Liver Dis 2010;42:490-495.

5 von Hahn T, Ciesek S, Wegener G, Plentz RR, Weismüller TJ, Wedemeyer H, Manns MP, Greten TF, Malek NP: Epidemiological trends in incidence and mortality of hepatobiliary cancers in Germany. Scand J Gastroenterol 2011;46:1092-1098.

6 Farley DR, Weaver AL, Nagorney DM: 'Natural history' of unresected cholangiocarcinoma: patient outcome after noncurative intervention. Mayo Clin Proc 1995;70:425-429.

7 Eckel F, Brunner T, Jelic S: Biliary cancer: ESMO Clinical Practice Guidelines for diagnosis, treatment and follow-up. Ann Oncol 2011;22:vi40-44.

$\checkmark 8$ Yusuf MA, Kapoor VK, Kamel RR, Kazmi A, Uddin N, Masood N, Al-Abdulkareem A: Modification and implementation of NCCN guidelines on hepatobiliary cancers in the Middle East and North Africa region. J Natl Compr Canc Netw 2010;8:36-40.

$\checkmark 9$ Ben-Josef E, Guthrie KA, El-Khoueiry AB, Corless CL, Zalupski MM, Lowy AM, Thomas CR Jr, Alberts SR, Dawson LA, Micetich KC, Thomas MB, Siegel AB, Blanke CD: SWOG S0809: a phase II intergroup trial of adjuvant capecitabine and gemcitabine followed by radiotherapy and concurrent capecitabine in extrahepatic cholangiocarcinoma and gallbladder carcinoma. J Clin Oncol 2015;33:2617-2622.
10 Glimelius B, Hoffman K, Sjödén PO, Jacobsson G, Sellström H, Enander LK, Linné T, Svensson C: Chemotherapy improves survival and quality of life in advanced pancreatic and biliary cancer. Ann Oncol 1996; 7:593-600

11 Patt YZ, Jones DV Jr, Hoque A, Lozano R, Markowitz A, Raijman I, Lynch P, Charnsangavej C: Phase II trial of intravenous flourouracil and subcutaneous interferon alfa-2b for biliary tract cancer. J Clin Oncol 1996; 14:2311-2315.

12 Harvey JH, Smith FP, Schein PS: 5-Fluorouracil, mitomycin, and doxorubicin (FAM) in carcinoma of the biliary tract. J Clin Oncol 1984;2:1245-1248.

13 Lee GW, Kang JH, Kim HG, Lee JS, Lee JS, Jang JS: Combination chemotherapy with gemcitabine and cisplatin as first-line treatment for immunohistochemically proven cholangiocarcinoma. Am J Clin Oncol 2006;29:127-131.

14 Ducreux M, Rougier P, Fandi A, Clavero-Fabri MC, Villing AL, Fassone F, Fandi L, Zarba J, Armand JP: Effective treatment of advanced biliary tract carcinoma using 5-fluorouracil continuous infusion with cisplatin. Ann Oncol 1998;9:653-656.

15 Ducreux M, Van Cutsem E, Van Laethem JL, Gress TM, Jeziorski K, Rougier P, Wagener T, Anak O, Baron B, Nordlinger B; EORTC Gastro Intestinal Tract Cancer Group: A randomised phase II trial of weekly high-dose 5-fluorouracil with and without folinic acid and cisplatin in patients with advanced biliary tract carcinoma: results of the 40955 EORTC trial. Eur J Cancer 2005;41:398-403.

16 Nehls O, Klump B, Arkenau HT, Hass HG, Greschniok A, Gregor M, Porschen R: Oxaliplatin, fluorouracil and leucovorin for advanced biliary system adenocarcinomas: a prospective phase II trial. Br J Cancer 2002;87: 702-704.
17 Nehls O, Oettle H, Hartmann JT, Hofheinz RD, Hass HG, Horger MS, Koppenhöfer U, Hochhaus A, Stieler J, Trojan J, Gregor M, Klump B: Capecitabine plus oxaliplatin as first-line treatment in patients with advanced biliary system adenocarcinoma: a prospective multicentre phase II trial. Br J Cancer 2008;98:309-315.

18 Okusaka T, Ishii H, Funakoshi A, Yamao K, Ohkawa S, Saito S, Saito H, Tsuyuguchi T: Phase II study of single-agent gemcitabine in patients with advanced biliary tract cancer. Cancer Chemother Pharmacol 2006;57: 647-653.

19 Kubicka S, Rudolph KL, Tietze MK, Lorenz M, Manns M: Phase II study of systemic gemcitabine chemotherapy for advanced unresectable hepatobiliary carcinomas. Hepatogastroenterology 2001;48:783-789.

20 Knox JJ, Hedley D, Oza A, Feld R, Siu LL, Chen E, Nematollahi M, Pond GR, Zhang J, Moore MJ: Combining gemcitabine and capecitabine in patients with advanced biliary cancer: a phase II trial. J Clin Oncol 2005;23:2332-2338.

21 Knox JJ, Hedley D, Oza A, Siu LL, Pond GR, Moore MJ: Gemcitabine concurrent with continuous infusional 5-fluorouracil in advanced biliary cancers: a review of the Princess Margaret Hospital experience. Ann Oncol 2004;15:770-774.

22 Cho JY, Paik YH, Chang YS, Lee SJ, Lee DK, Song SY, Chung JB, Park MS, Yu JS, Yoon DS: Capecitabine combined with gemcitabine (CapGem) as first-line treatment in patients with advanced/metastatic biliary tract carcinoma. Cancer 2005; 104:2753-2758.

23 Riechelmann RP, Townsley CA, Chin SN, Pond GR, Knox JJ: Expanded phase II trial of gemcitabine and capecitabine for advanced biliary cancer. Cancer 2007; 110:1307-1312. 
24 Koeberle D, Saletti P, Borner M, Gerber D, Dietrich D, Caspar CB, Mingrone W, Beretta K, Strasser F, Ruhstaller T, Mora O, Herrmann R; Swiss Group for Clinical Cancer Research: Patient-reported outcomes of patients with advanced biliary tract cancers receiving gemcitabine plus capecitabine: a multicenter, phase II trial of the Swiss Group for Clinical Cancer Research. J Clin Oncol 2008;26:3702-3708.

-25 Verderame F, Russo A, Di Leo R, Badalamenti G, Santangelo D, Cicero G, Valerio MR, Gulotta G, Tomasello G, Gebbia N, Fulfaro F: Gemcitabine and oxaliplatin combination chemotherapy in advanced biliary tract cancers. Ann Oncol 2006;17(suppl 7):vii68-72.

26 André T, Tournigand C, Rosmorduc O, Provent S, Maindrault-Goebel F, Avenin D, Selle F, Paye F, Hannoun L, Houry S, Gayet B, Lotz JP, de Gramont A, Louvet C; GERCOR Group: Gemcitabine combined with oxaliplatin (GEMOX) in advanced biliary tract adenocarcinoma: a GERCOR study. Ann Oncol 2004; 15:1339-1343.

27 André T, Reyes-Vidal JM, Fartoux L, Ross P, Leslie M, Rosmorduc O, Clemens MR, Louvet C, Perez N, Mehmud F, Scheithauer W: Gemcitabine and oxaliplatin in advanced biliary tract carcinoma: a phase II study. $\mathrm{Br} J$ Cancer 2008;99:862-867.

28 Valle J, Wasan H, Palmer DH, Cunningham D, Anthoney A, Maraveyas A, Madhusudan S, Iveson T, Hughes S, Pereira SP, Roughton M, Bridgewater J; ABC-02 Trial Investigators: Cisplatin plus gemcitabine versus gemcitabine for biliary tract cancer. N Engl J Med 2010;362:1273-1281.

29 Valle JW, Furuse J, Jitlal M, Beare S, Mizuno N, Wasan $\mathrm{H}$, Bridgewater J, Okusaka T: Cisplatin and gemcitabine for advanced biliary tract cancer: a meta-analysis of two randomised trials. Ann Oncol 2014;25:391-398.

30 Walter T, Horgan AM, McNamara M, McKeever L, Min T, Hedley D, Serra S, Krzyzanowska MK, Chen E, Mackay H, Feld R, Moore M, Knox JJ: Feasibility and benefits of second-line chemotherapy in advanced biliary tract cancer: a large retrospective study. Eur J Cancer 2013;49:329-335.

31 Lamarca A, Hubner RA, David Ryder W, Valle JW: Second-line chemotherapy in advanced biliary cancer: a systematic review. Ann Oncol 2014;25:2328-2338.

- 32 Yoshikawa D, Ojima H, Iwasaki M, Hiraoka N, Kosuge T, Kasai S, Hirohashi S, Shibata T: Clinicopathological and prognostic significance of EGFR, VEGF, and HER2 expression in cholangiocarcinoma. Br J Cancer 2008;98:418-425.

33 Harder J, Waiz O, Otto F, Geissler M, Olschewski M, Weinhold B, Blum HE, Schmitt-Graeff A, Opitz OG: EGFR and HER2 expression in advanced biliary tract cancer. World J Gastroenterol 2009;15:4511-4517.

34 Andersen JB, Spee B, Blechacz BR, Avital I, Komuta M, Barbour A, Conner EA, Gillen MC, Roskams T, Roberts LR, Factor VM, Thorgeirsson SS: Genomic and genetic characterization of cholangiocarcinoma identifies therapeutic targets for tyrosine kinase inhibitors. Gastroenterology 2012;142:1021-1031.e15.

35 Yang X, Wang W, Wang C, Wang L, Yang M, Qi M, Su H, Sun X, Liu Z, Zhang J, Qin X, Han B: Characterization of EGFR family gene aberrations in cholangiocarcinoma. Oncol Rep 2014;32:700-708.

-36 Gruenberger B, Schueller J, Heubrandtner U, Wrba F, Tamandl D, Kaczirek K, Roka R, Freimann-Pircher S, Gruenberger T: Cetuximab, gemcitabine, and oxaliplatin in patients with unresectable advanced or metastatic biliary tract cancer: a phase 2 study. Lancet Oncol 2010;11:1142-1148.

37 Malka D, Cervera P, Foulon S, et al.; BINGO investigators: Gemcitabine and oxaliplatin with or without cetuximab in advanced biliary-tract cancer (BINGO): a randomised, open-label, non-comparative phase 2 trial. Lancet Oncol 2014;15:819-828.
38 Chen JS, Hsu C, Chiang NJ, et al.; Taiwan Cooperative Oncology Group: A KRAS mutation status-stratified randomized phase II trial of gemcitabine and oxaliplatin alone or in combination with cetuximab in advanced biliary tract cancer. Ann Oncol 2015;26:943-949.

39 Vogel A, Kasper S, Weichert W, Bitzer M, Block A, Riess H, Schulze-Bergkamen H, Moehler MH, Merx KE, Endris V, Schnoy E, Siveke JT, Michl P, Waldschmidt D, Kuhlmann J, Geissler M, Kahl C, Kubicka S: Panitumumab in combination with gemcitabine/ cisplatin (GemCis) for patients with advanced KRAS WT biliary tract cancer: a randomized phase II trial of the Arbeitsgemeinschaft Internistische Onkologie (AIO). J Clin Oncol 2015;33(suppl):abstr 4082.

40 Lee J, Park SH, Chang HM, Kim JS, Choi HJ, Lee MA, Jang JS, Jeung HC, Kang JH, Lee HW, Shin DB, Kang HJ, Sun JM, Park JO, Park YS, Kang WK, Lim HY: Gemcitabine and oxaliplatin with or without erlotinib in advanced biliary-tract cancer: a multicentre, openlabel, randomised, phase 3 study. Lancet Oncol 2012; 13:181-188.

41 Lubner SJ, Mahoney MR, Kolesar JL, Loconte NK, Kim GP, Pitot HC, Philip PA, Picus J, Yong WP, Horvath L, Van Hazel G, Erlichman CE, Holen KD: Report of a multicenter phase II trial testing a combination of biweekly bevacizumab and daily erlotinib in patients with unresectable biliary cancer: a phase II Consortium study. J Clin Oncol 2010;28:3491-3497.

42 Zhu AX, Meyerhardt JA, Blaszkowsky LS, Kambadakone AR, Muzikansky A, Zheng H, Clark JW, Abrams TA, Chan JA, Enzinger PC, Bhargava P, Kwak EL, Allen JN, Jain SR, Stuart K, Horgan K, Sheehan S, Fuchs CS, Ryan DP, Sahani DV: Efficacy and safety of gemcitabine, oxaliplatin, and bevacizumab in advanced biliary-tract cancers and correlation of changes in 18-fluorodeoxyglucose PET with clinical outcome: a phase 2 study. Lancet Oncol 2010;11:48-54.

43 Bengala C, Bertolini F, Malavasi N, Boni C, Aitini E, Dealis C, Zironi S, Depenni R, Fontana A, Del Giovane C, Luppi G, Conte P: Sorafenib in patients with advanced biliary tract carcinoma: a phase II trial. $\mathrm{Br} \mathrm{J}$ Cancer 2010;102:68-72.

44 El-Khoueiry AB, Rankin CJ, Ben-Josef E, Lenz HJ, Gold PJ, Hamilton RD, Govindarajan R, Eng C, Blanke CD: SWOG 0514: a phase II study of sorafenib in patients with unresectable or metastatic gallbladder carcinoma and cholangiocarcinoma. Invest New Drugs 2012;30:1646-1651.

45 Lee JK, Capanu M, O’Reilly EM, Ma J, Chou JF, Shia J, Katz SS, Gansukh B, Reidy-Lagunes D, Segal NH, Yu KH, Chung KY, Saltz LB, Abou-Alfa GK: A phase II study of gemcitabine and cisplatin plus sorafenib in patients with advanced biliary adenocarcinomas. $\mathrm{Br} \mathrm{J}$ Cancer 2013;109:915-919.

46 Moehler M, Maderer A, Schimanski C, et al.; Working Group of Internal Oncology: Gemcitabine plus sorafenib versus gemcitabine alone in advanced biliary tract cancer: a double-blind placebo-controlled multicentre phase II AIO study with biomarker and serum programme. Eur J Cancer 2014;50:3125-3135.

47 El-Khoueiry AB, Rankin C, Siegel AB, Iqbal S, Gong IY, Micetich KC, Kayaleh OR, Lenz HJ, Blanke CD: S0941: a phase 2 SWOG study of sorafenib and erlotinib in patients with advanced gallbladder carcinoma or cholangiocarcinoma. Br J Cancer 2014;110:882-887.

48 Valle JW, Wasan H, Jitlal M, Backen AC, Palmer DH, Duggan M, Cunningham D, Anthoney DA, Corrie P, Madhusudan S, Maraveyas A, Ross PJ, Waters JS, Steward WP, Rees C, Beare S, Dive C, Bridgewater JA: ABC-03: a randomized phase II trial of cediranib (AZD2171) or placebo in combination with cisplatin/ gemcitabine (CisGem) chemotherapy for patients (pts) with advanced biliary tract cancer (ABC). J Clin Oncol 2014;32(suppl 5):abstr 4002.
49 Yi JH, Thongprasert S, Lee J, Doval DC, Park SH, Park JO, Park YS, Kang WK, Lim HY: A phase II study of sunitinib as a second-line treatment in advanced biliary tract carcinoma: a multicentre, multinational study. Eur J Cancer 2012;48:196-201.

50 Santoro A, Gebbia V, Pressiani T, Testa A, Personeni N, Arrivas Bajardi E, Foa P, Buonadonna A, Bencardino K, Barone C, Ferrari D, Zaniboni A, Tronconi MC, Cartenì G, Milella M, Comandone A, Ferrari S, Rimassa L: A randomized, multicenter, phase II study of vandetanib monotherapy versus vandetanib in combination with gemcitabine versus gemcitabine plus placebo in subjects with advanced biliary tract cancer: the VanGogh study. Ann Oncol 2015;26:542-547.

51 Bekaii-Saab T, Phelps MA, Li X, Saji M, Goff L, Kauh JS, O’Neil BH, Balsom S, Balint C, Liersemann R, Vasko VV, Bloomston M, Marsh W, Doyle LA, Ellison G, Grever M, Ringel MD, Villalona-Calero MA: Multiinstitutional phase II study of selumetinib in patients with metastatic biliary cancers. J Clin Oncol 2011;29: 2357-2363.

2 Sasaki T, Isayama H, Nakai Y, Ito Y, Yasuda I, Toda N, Kogure H, Hanada K, Maguchi H, Sasahira N, Kamada H, Mukai T, Okabe Y, Hasebe O, Maetani I, Koike K: A randomized phase II study of gemcitabine and S-1 combination therapy versus gemcitabine monotherapy for advanced biliary tract cancer. Cancer Chemother Pharmacol 2013;71:973-979.

$53 \mathrm{Li} \mathrm{H}$, Zhang ZY, Zhou ZQ, Guan J, Tong DN, Zhou GW: Combined gemcitabine and S-1 chemotherapy for treating unresectable hilar cholangiocarcinoma: a randomized open-label clinical trial. Oncotarget 2016; 7:26888-26897.

54 Pant S, Saleh M, Bendell J, Infante JR, Jones S, Kurkjian CD, Moore KM, Kazakin J, Abbadessa G, Wang Y, Chen Y, Schwartz B, Camacho LH: A phase I dose escalation study of oral c-MET inhibitor tivantinib (ARQ 197) in combination with gemcitabine in patients with solid tumors. Ann Oncol 2014;25:1416-1421.

55 Lipka Goyal MBY, Abrams TA, Kwak EL, Cleary JM, Knowles M, Regan E, Gisondi A, Sheehan S, Zheng H, Zhu AX: A phase II trial of cabozantinib (XL-184) in patients with advanced cholangiocarcinoma. J Clin Oncol 2015;33(suppl 3):abstr 800

56 Voss JS, Holtegaard LM, Kerr SE, Fritcher EG, Roberts LR, Gores GJ, Zhang J, Highsmith WE, Halling KC, Kipp BR: Molecular profiling of cholangiocarcinoma shows potential for targeted therapy treatment. Hum Pathol 2013;44:1216-1222.

57 Grassian AR, Pagliarini R, Chiang DY: Mutations of isocitrate dehydrogenase 1 and 2 in intrahepatic cholangiocarcinoma. Curr Opin Gastroenterol 2014;30: 295-302.

58 Aruga A, Takeshita N, Kotera Y, Okuyama R, Matsushita N, Ohta T, Takeda K, Yamamoto M: Phase I clinical trial of multiple-peptide vaccination for patients with advanced biliary tract cancer. J Transl Med 2014;12:61.

59 Sabbatino F, Villani V, Yearley JH, Deshpande V, Cai L, Konstantinidis IT, Moon C, Nota S, Wang Y, AlSukaini A, Zhu AX, Goyal L, Ting DT, Bardeesy N, Hong TS, Fernandez-del Castillo C, Tanabe KK, Lillemoe KD, Ferrone S, Ferrone CR: PD-L1 and HLA class I antigen expression and clinical course of the disease in intrahepatic cholangiocarcinoma. Clin Cancer Res 2016;22:470-478.

60 Gani F, Nagarajan N, Kim Y, Zhu Q, Luan L, Bhaijjee F, Anders RA, Pawlik TM: Program death 1 immune checkpoint and tumor microenvironment: implications for patients with intrahepatic cholangiocarcinoma. Ann Surg Oncol 2016;23:2610-2617. 